\title{
Prolonging the productive use period cows guarantee a reduction in the cost of milk
}

\author{
A.A. Askarov, and A.A. Askarova* \\ FGBOU in Bashkir Gau, Ufa, Russia
}

\begin{abstract}
In the article using correlation and regression analysis, it is shown what a negative impact on the indicators of the economic efficiency of dairy cattle breeding has an unreasonable transition to more intensive technologies of industry, resulting in a loss of the existing competitive advantages of the industry and a significant increase in the cost of products. The situation can be corrected if less costly traditional technology based on the highest possible use of natural feed grounds in pasture-stall or stall-pasture contents in the milk cattle breeding. As a result, the duration of the use of cows will increase before reaching the greatest productivity, the possibility of breeding is improved, which in turn guarantees an increase in milk productivity in the herd, reducing the costs of reproduction of a productive herd and a decrease in production costs. The purpose of our study is to show the leaders of agrarian formations of economic consequences of changing the terms of the productive use of cows, relying on which they could conduct targeted work on the cheaper production and the increase in the competitiveness of milk and other cattle breeding.
\end{abstract}

\section{Introduction}

The study is devoted to identifying factors that have a negative impact on the profitability of milk production and preventing the growth of its financial competitiveness and substantiates the need to revive less costly technology in dairy cattle breeding based on pasture-stall or stall-pasture content systems. At the same time, the authors focused on the use of factual information, which has a high degree of verifiable. Thus, the action of the law of a decreasing return of resources is illustrated using reporting data for 3 years of one largest (the average annual number of cows reaches 3 thousand heads) and the method of correlation and regression analysis of statistical data with the application of the application package effectively operating in the Region of "Limited Liability Company" Stadia 6.0. When calculating possible reserves of reducing costs in dairy cattle breeding related to the elongation of the productive use of cows, reporting data (forms are: No. 8-APK, No. 13APK) of agricultural organizations subordinate to the Ministry of Agriculture of the Republic of Bashkortostan for 2019 were used.

\footnotetext{
* Corresponding author: dalina2004@mail.ru
} 
The relevance of the study is that it is devoted to the problem of increasing the competitiveness of dairy cattle breeding, which is the basis of the well-being of rural territories. Despite the presence of serious theoretical studies of scientists, as well as practical experience in obtaining competitive agricultural products while maintaining traditional technologies, including in economically developed European countries, the leaders of the industry of our country are largely ignored. This means the need to submit verified practices for proposals to improve the competitiveness of dairy cattle breeding and the development of the methodology for forecasting and strategic planning on the sectoral level.

Our goal is to show the leaders of agrarian formations of some laws and patterns inherent in the economy as a whole and the economy of agricultural production in particular, relying on which they could conduct targeted work on improving the competitiveness of their products, respectively, the sustainability of the functioning in the long term. In this regard, it is important to remember that the planning of any decision that requires the investment of additional funds must be substantiated by the estimation of its effectiveness. For example, the effectiveness of changing the norm and structure of feeding cows in order to increase their productivity is determined by the difference between the cost of additional products obtained as a result of the use of more better than the nutritional feed in the diet and the cost of these additional feeds. The problem is that the milk yield on each consistently spent unit of feed, it is growing first, and in the future, from some moment, with an increase in the cost of feed, the milk yield begins to decrease - the moment occurs when this difference becomes a negative value - additional investments. The increase in livestock feeding intensity is based on a loss, so the law of reducing returns of resources is valid.

\section{Results and discussion}

As A. Zotov, a project manager for the creation of technological decisions in the field of agriculture, Vit-Consulting - "So far, the false doctrine is broadcast at the highest level at the highest level: the more productivity, the higher the profits". Such the thesis is not confirmed by practice - it turns out that "... the higher the productivity of the cows, the more expensive production of milk" [1,2]. This conclusion was once again confirmed and when analyzing the correlation dependence of the cost of milk (y1, rubles / kg) and the level of its profitability (Y2,\%) on the intensity of the management of dairy cattle breeding (X, production costs per Cow, thousand rubles) (Figures 1,2).

The reason for such "behavior" of curve of dependence is that a further increase in productivity requires the cost of resources, in particular feeds per head, which increase with greater speed than the milk productivity of the cow.

$\mathrm{Y} 1=23,81-0,1496 \mathrm{X}+0,001076 \mathrm{X}^{2} ; \mathrm{R}=0,780 ; \mathrm{R}^{2}=0,608 ; \mathrm{F}=17,84 ;$

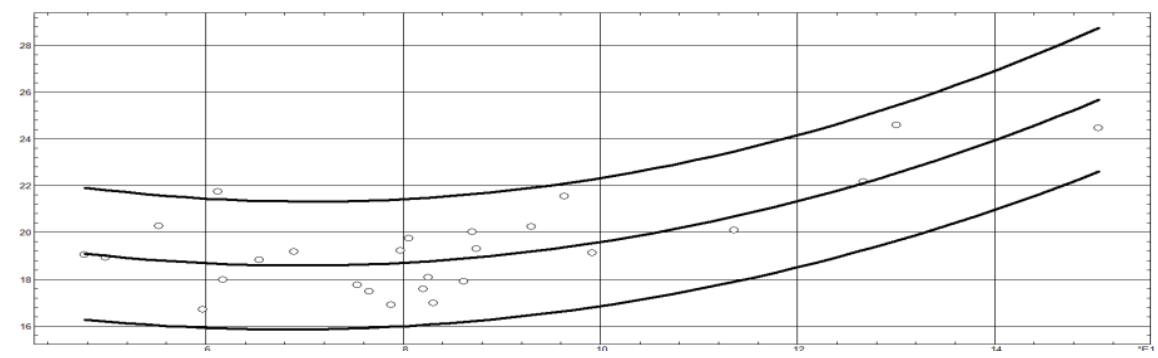

Fig. 1. The dependence of the cost of milk from the level of intensity of making dairy cattle breeding. 
Figure 2 shows the curve, which represents the "inverted" [3] parabola. Reducing the level of profitability is due at the same time, in the first year, the increase in the value of the diet of high-handed cows; Secondly, the costs of reproduction of the dairy flock associated with a multiple reduction in the deadlines of the possible productive use of cows. In this regard, the authors consider the search for optimal technologies and methods for the content of livestock, allowing to increase the profitability of the industry.

Instead of spending their material and monetary resources in the direction of increasing milk production by increasing the annual productivity of cows, not as follows that it leads to a significant increase in the cost of final products, experts and scientists recommend leading actively to lengthen the productive use of cows Which in the context of the Republic of Bashkortostan amounted to an average of 3.7 lactation (2019), and in one large dairy complex (in the suburb of Ufa), the economic use of cows in the last few years only 2.0-2.7 lactations in the last few years. As a result of this, the replacement of the folded cows becomes possible only by the permanent purchase of repair young people, which costs 2 times more expensive compared to the cultivation of strictly selected in the dairy productivity of chickle mothers in its own economy.

$$
\mathrm{Y} 2=-13,08+0,9515 \mathrm{X}-0,00613 \mathrm{X}^{2} ; \mathrm{R}=0,731 ; \mathrm{R}^{2}=0,535 ; \mathrm{F}=11,50
$$

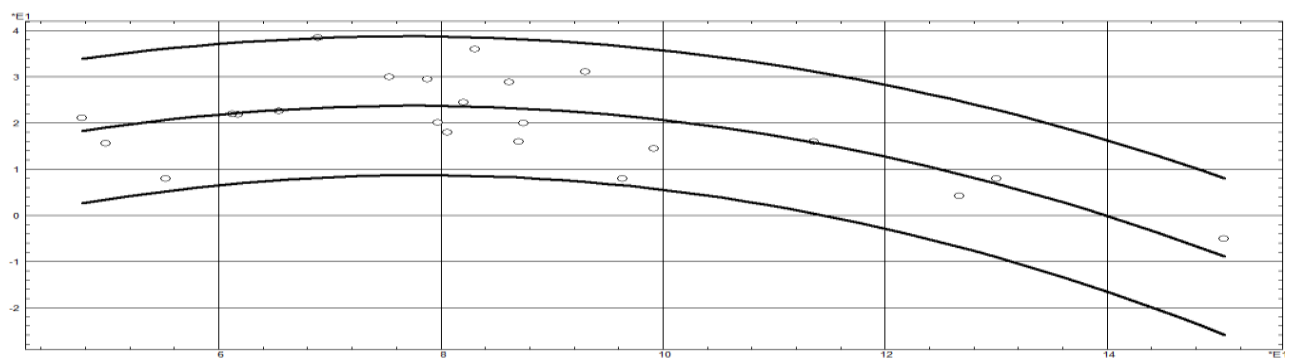

Fig. 2. Milk profitability dependence from the intensity of making milk cattle breeding

But, the latter is only possible when the cow has time to go to her life at least 5-6 times.

For comparison, we give a few examples from foreign practice - on Israeli cow farms live and give milk to 20 years [4-7]; In New Zealand, the number of lactations varies from 4 to 11 , with the average productivity of cows -4 thousand liters. According to the head of the project of the New Zealand company "AMG Pastoral" A. Zotov: "The Credo of Farmers of New Zealand is formulated as:" It has not yet been possible to increase profits by increasing the fun, the only way is to reduce costs "[2].

In these countries, in particular, the opinions are held that the elongation of the productive use of the cow is the most important factor in improving the efficiency and competitiveness of dairy cattle breeding $[1,2]$. To the same conclusion came from the results of his research E.h. Treurena [8], according to the calculations of which (according to the actual data of one of the farms of the Leningrad region), lengthening the term of productive use of cows from 2.9 to 3.3 years, guarantees an increase of at the entire flock (1451 cow) by 5 percent or by 63.0 thousand dollars.

In determining possible reserves to reduce the cost of milk associated with the elongation of the productive use of cows, we decided to calculate several scenarios of the functioning of the farm of the dairy direction - in the first version of the productive use of the cow adopted for 4 years, in the second - 8 years, that is, after the end of the productive The life cycle of the cow is chosen and the livestock is updated - at the end of the fourth and eighth years - integers (without fractional parts) are adopted for the convenience of calculations and interpretation of the results. In case of rallies of the parameters presented in the first and second scenarios, the following data and assumptions were used:

1 ) the price of the sale of milk is the average formed in the reporting year (21,59 rubles / 
$\mathrm{kg})$;

2) The amount of receipt from the cow's cow is determined at the price of the sale of cattle on the meat in live weight (in the year of replacement $-550 \mathrm{~kg} /$ goal). In this case, option 1 provides for the chipping of the cow and its replacement after 4 hotels ( 2 heads for 8 years), option 2 - after 8 calves ( 1 head);

3 ) the amount of receipt from the selection is adopted equal to the cost of one head, since it was not possible to determine the reliable sales prices;

4) Costs related to the replenishment of the livestock (steel repairs) at the level of 83.0 thousand rubles. included in the composition of permanent costs - in the 1 st and 5 th years of lactation (in Embodiment 1);

5) the average annual fishing by year is designed at the level of commodity production of milk, taking into account the lactation curve [9];

6 ) in determining the cost of milk (rubles $/ \mathrm{kg}$ ), production costs per cow were divided into permanent and variables according to the form No. 8-APC annual report.

In the third version of the scenario, in contrast to the second, it is planned to change the structure of the feed base towards the decrease in the share of concentrated feed (by 7 percentage points - from 42 to 35\%) and the corresponding increase in the share of green feeds with natural pastures - "free resource for increasing profitability in rural economy "[10]. The consequences of the implementation of this event are, reducing the cost of feed per cow at least 10 percent by increasing the cost of feeding rations (according to the results of our previous studies) in terms of direct variable costs (3.6 thousand / goals). The same savings are assumed in the cost of feed related to the replenishment of cows (4.0 thousand rubles / goal).

These calculations are presented in the table 1.

Table 1. Milk Production Efficiency Indicators

with different scenarios of productive use of cows

\begin{tabular}{|c|c|c|c|c|c|c|c|c|c|}
\hline \multirow{2}{*}{ Indicators } & \multicolumn{8}{|c|}{ Years of productive use of cows } & \multirow{2}{*}{$\begin{array}{l}\text { Behind } \\
8 \text { years }\end{array}$} \\
\hline & 1 & 2 & 3 & 4 & 5 & 6 & 7 & 8 & \\
\hline \multicolumn{10}{|c|}{ Option 1. The term of productive use of the cow - up to 4 hotels (milk profitability $=24.7 \%$ ) } \\
\hline $\begin{array}{l}\text { 1. Costs total, thousand } \\
\text { rubles, including: } \\
\text { permanent } \\
\text { variables }\end{array}$ & $\begin{array}{c}149,3 \\
108,0 \\
41,3 \\
\end{array}$ & $\begin{array}{l}74,3 \\
25,0 \\
49,3\end{array}$ & $\begin{array}{l}78,9 \\
25,0 \\
53,9 \\
\end{array}$ & $\begin{array}{l}80,1 \\
25,0 \\
55,1\end{array}$ & $\begin{array}{c}149,3 \\
108,0 \\
41,3 \\
\end{array}$ & $\begin{array}{l}74,3 \\
25,0 \\
49,3 \\
\end{array}$ & $\begin{array}{l}78,9 \\
25,0 \\
53,9 \\
\end{array}$ & $\begin{array}{l}80,1 \\
25,0 \\
55,1 \\
\end{array}$ & $\begin{array}{l}765,2 \\
366,0 \\
399,2 \\
\end{array}$ \\
\hline $\begin{array}{l}\text { 2. Average annual fishing, } \\
\text { centner/goals. }\end{array}$ & 36 & 43 & 47 & 48 & 36 & 43 & 47 & 48 & 43,5 \\
\hline $\begin{array}{l}\text { 3. Milk proceeds, thousand } \\
\text { rubles. }\end{array}$ & 77,7 & 92,8 & 101,5 & 103,6 & 77,7 & 92,8 & 101,5 & 103,6 & 751,2 \\
\hline $\begin{array}{l}\text { 4. Receipts at the expense } \\
\text { of the rating } \\
\text { and chipping cows, } \\
\text { thousand rubles. }\end{array}$ & 10,0 & 10,0 & 10,0 & 68,0 & 10,0 & 10,0 & 10,0 & 68,0 & 196,0 \\
\hline $\begin{array}{l}\text { 5. Income, total, thousand } \\
\text { rubles. }\end{array}$ & 87,7 & 102,8 & 111,5 & 171,6 & 87,7 & 102,8 & 111,5 & 171,6 & 947,2 \\
\hline $\begin{array}{l}6 \text {. The difference between } \\
\text { arrivals } \\
\text { and production costs, } \\
\text { thousand rubles. }\end{array}$ & $-61,6$ & 28,5 & 32,6 & 91,5 & $-61,6$ & 28,5 & 32,6 & 91,5 & 182,0 \\
\hline 7. Cost of milk, rub. / kg & 18,42 & 17,28 & 16,79 & 16,69 & 18,42 & 17,28 & 16,79 & 16,69 & 17,32 \\
\hline
\end{tabular}




\begin{tabular}{|c|c|c|c|c|c|c|c|c|c|}
\hline $\begin{array}{l}\text { 1. Costs total, thousand } \\
\text { rubles, including: } \\
\text { permanent } \\
\text { variables }\end{array}$ & $\begin{array}{c}149,3 \\
108,0 \\
41,3\end{array}$ & $\begin{array}{l}74,3 \\
25,0 \\
49,3\end{array}$ & $\begin{array}{l}78,9 \\
25,0 \\
53,9\end{array}$ & $\begin{array}{l}80,1 \\
25,0 \\
55,1\end{array}$ & $\begin{array}{l}82,4 \\
25,0 \\
57,4\end{array}$ & $\begin{array}{l}83,5 \\
\\
25,0 \\
58,5\end{array}$ & $\begin{array}{l}78,9 \\
25,0 \\
53,9\end{array}$ & $\begin{array}{l}74,3 \\
25,0 \\
49,3\end{array}$ & $\begin{array}{l}701,7 \\
283,0 \\
418,7\end{array}$ \\
\hline $\begin{array}{l}\text { 2. Average annual fishing, } \\
\text { centner/goals. }\end{array}$ & 36 & 43 & 47 & 48 & 50 & 51 & 47 & 43 & 45,6 \\
\hline $\begin{array}{l}\text { 3. Milk proceeds, thousand } \\
\text { rubles. }\end{array}$ & 77,7 & 92,8 & 101,5 & 103,6 & 108,0 & 110,1 & 101,5 & 92,8 & 788,0 \\
\hline $\begin{array}{l}\text { 4. Receipts at the expense } \\
\text { of the rating } \\
\text { and chipping cows, } \\
\text { thousand rubles. }\end{array}$ & 10,0 & 10,0 & 10,0 & 10,0 & 10,0 & 10,0 & 10,0 & 68,0 & 138,0 \\
\hline $\begin{array}{l}\text { 5. Income, total, thousand } \\
\text { rubles. }\end{array}$ & 87,7 & 102,8 & 111,5 & 113,6 & 118,0 & 120,1 & 111,5 & 160,8 & 926,0 \\
\hline $\begin{array}{l}\text { 6. The difference between } \\
\text { arrivals } \\
\text { and production costs, } \\
\text { thousand rubles. }\end{array}$ & $-61,6$ & 28,5 & 32,6 & 33,5 & 35,6 & 36,6 & 32,6 & 86,5 & 224,3 \\
\hline 7. Cost of milk, rub. / kg & 18,42 & 17,28 & 16,79 & 16,69 & 16,48 & 16,37 & 16,79 & 17,28 & 16,68 \\
\hline \multicolumn{10}{|c|}{ Option 3. The term of productive use of the cow - up to 8 hotels (milk profitability $=33.5 \%$ ) } \\
\hline $\begin{array}{l}\text { 1. Costs total, thousand } \\
\text { rubles, including: } \\
\text { permanent } \\
\text { variables }\end{array}$ & $\begin{array}{c}141,7 \\
104,0 \\
37,7\end{array}$ & $\begin{array}{l}70,7 \\
25,0 \\
45,7\end{array}$ & $\begin{array}{l}75,3 \\
25,0 \\
50,3\end{array}$ & $\begin{array}{l}76,5 \\
25,0 \\
51,5\end{array}$ & $\begin{array}{l}78,8 \\
25,0 \\
53,8\end{array}$ & $\begin{array}{l}79,9 \\
25,0 \\
54,9\end{array}$ & $\begin{array}{l}75,3 \\
25,0 \\
50,3\end{array}$ & $\begin{array}{l}70,7 \\
25,0 \\
45,7\end{array}$ & $\begin{array}{l}668,9 \\
279,0 \\
389,9\end{array}$ \\
\hline $\begin{array}{l}\text { 2. Average annual fishing, } \\
\text { centner/goals. }\end{array}$ & 36 & 43 & 47 & 48 & 50 & 51 & 47 & 43 & 45,6 \\
\hline $\begin{array}{l}\text { 3. Milk proceeds, thousand } \\
\text { rubles. }\end{array}$ & 77,7 & 92,8 & 101,5 & 103,6 & 108,0 & 110,1 & 101,5 & 92,8 & 788,0 \\
\hline $\begin{array}{l}\text { 4. Receipts at the expense } \\
\text { of the rating } \\
\text { and chipping cows, } \\
\text { thousand rubles. }\end{array}$ & 10,0 & 10,0 & 10,0 & 10,0 & 10,0 & 10,0 & 10,0 & 68,0 & 138,0 \\
\hline $\begin{array}{l}\text { 5. Income, total, thousand } \\
\text { rubles. }\end{array}$ & 87,7 & 102,8 & 111,5 & 113,6 & 118,0 & 120,1 & 111,5 & 160,8 & 926,0 \\
\hline $\begin{array}{l}\text { 6. The difference between } \\
\text { arrivals } \\
\text { and production costs, } \\
\text { thousand rubles. }\end{array}$ & $-54,0$ & 32,1 & 36,2 & 37,1 & 39,2 & 40,2 & 36,2 & 90,1 & 257,1 \\
\hline 7. Cost of milk, rub. / kg & 17,42 & 16,44 & 16,02 & 15,94 & 15,76 & 15,67 & 16,02 & 16,44 & 16,17 \\
\hline
\end{tabular}

\section{Conclusion}

1. As can be seen from Figures 1-2, an increase in the level of production intensity due to an increase in logistical costs per head in order to increase the productivity of cows is economically acquitted only to a certain level - the further increase in productivity is accompanied by a significant increase in production costs, key factor determining product competitiveness. Thus, in this paragraph, this conclusion can be made from the point of view of production efficiency, the optimal annual productivity in the context of the Republic of Bashkortostan, taking into account the feed base and the conditions of content, is $4,000-4500 \mathrm{~kg}$ of milk per cow, while the level of profitability of production is It will be maximum.

2. The results of the calculations shown in the table show - an increase in the term of 
productive use of the cow increases the economic efficiency of production of products as a whole in the herd, that is, hypothesis is confirmed that a less intense feeding system and the content of dairy cows is more efficient in modern conditions, in particular, in the context of the Republic of Bashkortostan.

Such a management system guarantees the sustainable production of the optimal level of productivity at a lower cost of a unit of products. In addition, the technology based on the pasture-stall or stall and pasture content of cattle will allow farms to receive additional profits through the sale of an unnecessary amount of repair young (chicks and / or nonflames) to the side - peasant (farmer), as well as personal subsidiary farms. With the first placement of production activities, such sale is practically excluded - problems with the repair of their own dairy herds may arise.

3. Increased the share of green feeds in cows' rations due to natural pastures, in addition to the cheapening of feeding, it will also be favorable for animal health - less reasons for the forced chipping of cows and will also lead to the release of part of arable land that can be directed to an increase in sowing areas Agricultural crops having high marginality. Accordingly, the economic efficiency of the branch of crop production and the economy as a whole will increase. True, it is forced to note that the consequences of this item did not find a quantitative assessment due to the lack of available reliable information from the authors.

\section{References}

1. N.A. Lartin, A.A. Zotov, Milk-Pasture Cluster of New Zealand Source, http://milknews.ru

2. A. Chernov, Dairy News.ru, https://www.dairynews.ru/hotcomments/rossiyskayako rovamolochnogoeksporta/andrey-zotov-predstavitel-amg-pastoral-ltd-v-rf-kons.html

3. Yu.N. Nikulina, The influence of the concentration of milk production on its competitiveness in S.-H. organizations of the Leningrad region, (Author. diss. Cand. Econ. Sciences (St. Petersburg, Pushkin, 2011)

4. M.J. Bell, E. Wall, G. Russell, G. Simm, A.W. Stott, Journal of Dairy Science, 94 (7), 3662-3678, (2011) doi: 10.3168/jds.2010-4023

5. M.J. Bell, R.J. Eckard, M. Haile-Mariam, J.E. Pryce, Journal of Dairy Science, 96 (12), 7918-7931 (2013) doi: 10.3168/jds.2010-4023

6. M.J. Bell, P. Wilson, Food and Energy Security 7 (1), e00127, (2018) doi: $10.1002 /$ fes 3.127

7. A.A. Dijkhuizen, J.A.Renkema, J. Stelwagen, Preventive Veterinary Medicine, 3 (3), 265-276 (1985) doi: 10.1016/0167-5877(85)90021-2

8. E.h. Treurena, Milk production profitability management with information technology, Increase the competitiveness of milk production in agricultural organizations (recommendations) (SPb.: GNU Szniesk, 2009)

9. K.-D. Bauer, G.N. Harlamova, L.I. Mosina, T.I. Pavlushina, Economy of the agricultural enterprise (Kostroma State Agricultural Academy, 280, 1999)

10. T. Sazonov, Free resource for increasing profitability in agriculture, https://npobiocentr.ru/ stati/rastenievodstvo-resurs-zadarom-pochemu-zdorove-pochvystanovitsya-klyuchevym-ponyatiem-v-rastenievodstve/ 